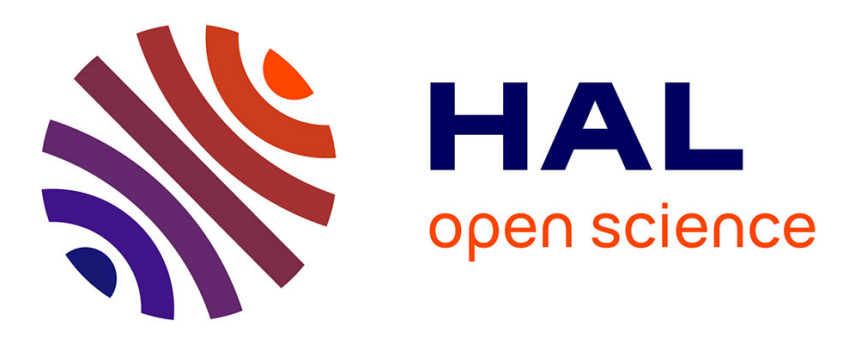

\title{
The diet of an invasive nonnative predator, the feral ferret, and implications for the conservation of ground-nesting birds
}

Thomas W. Bodey, Stuart Bearhop, Robbie A. Mcdonald

\section{To cite this version:}

Thomas W. Bodey, Stuart Bearhop, Robbie A. Mcdonald. The diet of an invasive nonnative predator, the feral ferret, and implications for the conservation of ground-nesting birds. European Journal of Wildlife Research, 2010, 57 (1), pp.107-117. 10.1007/s10344-010-0404-y · hal-00599783

\section{HAL Id: hal-00599783 \\ https://hal.science/hal-00599783}

Submitted on 11 Jun 2011

HAL is a multi-disciplinary open access archive for the deposit and dissemination of scientific research documents, whether they are published or not. The documents may come from teaching and research institutions in France or abroad, or from public or private research centers.
L'archive ouverte pluridisciplinaire HAL, est destinée au dépôt et à la diffusion de documents scientifiques de niveau recherche, publiés ou non, émanant des établissements d'enseignement et de recherche français ou étrangers, des laboratoires publics ou privés. 


\title{
The diet of an invasive nonnative predator, the feral ferret Mustela furo, and implications for the conservation of ground-nesting birds
}

\author{
Thomas W. Bodey • Stuart Bearhop • \\ Robbie A. McDonald
}

Received: 10 July 2009/Revised: 17 May 2010/Accepted: 21 May 2010/Published online: 11 June 2010

(C) Springer-Verlag 2010

\begin{abstract}
Introduced carnivores have had a significant impact on the fauna of a number of countries, particularly on islands. In the British Isles, several offshore islands holding internationally important aggregations of seabirds and shorebirds support self-sustaining feral ferret Mustela furo populations, often as the top terrestrial predator. However, little is known about the interactions between ferrets and both native and nonnative prey in these locations. We examined the diet of feral ferrets on Rathlin Island, Northern Ireland. We determined the frequency of occurrence of prey items and constructed energetic models to determine their potential impact on both native and introduced prey. Rabbits Oryctolagus cuniculus occurred in $75 \%$ of scats, while birds, carrion, and brown rats Rattus norvegicus were important secondary items. There was little difference between the diets of males and females. Estimates of the energy requirements of the population at current, and with hypothetically reduced, rabbit availability revealed the potential for carrion to maintain the ferret population over winter. Management options could thus focus on reducing
\end{abstract}

Communicated by H. Kierdorf

T. W. Bodey

Quercus, Queen's University Belfast,

97 Lisburn Road,

Belfast BT9 7BL, UK

T. W. Bodey $(\bowtie) \cdot$ S. Bearhop

Centre for Ecology and Conservation, University of Exeter,

Cornwall Campus,

Penryn TR10 9EZ, UK

e-mail: T.W.Bodey@exeter.ac.uk

R. A. McDonald

Food and Environment Research Agency,

Sand Hutton,

York YO41 1LZ, UK anthropogenic food sources as an immediate way of mitigating the threat to ground-nesting birds, while other strategies, including eradication, are considered.

Keywords Hyperpredation · Invasive species · Island · Management $\cdot$ Mustelid $\cdot$ Oryctolagus cuniculus

\section{Introduction}

The introduction of generalist mammalian predators to new environments often has significant detrimental consequences for the native fauna (Veitch and Clout 2002; Courchamp et al. 2003a). These effects are particularly pronounced on islands, which often support species that are unable to adapt to increases in predation (Pitta Groz et al. 2002; Courchamp et al. 2003a; Blackburn et al. 2004). The majority of such conservation problems have been caused by a few widely distributed commensal, companion, and domesticated animals such as cats Felis catus, pigs Sus scrofa, and rats Rattus spp. (Atkinson 1989; Roemer et al. 2002; Veitch and Clout 2002; Jones et al. 2008). However, small carnivores such as mustelids can have similarly devastating impacts where they have been introduced (e.g., Macdonald and Harrington 2003; Clapperton and Byrom 2005).

The most significant example of the impacts of feral ferrets Mustela furo has been in New Zealand, where they represent both an important economic threat as vectors of bovine tuberculosis Mycobacterium bovis (Caley and Hone 2005) and a substantial conservation threat to the native fauna. It is therefore not surprising that most of the significant studies into feral ferret ecology and behaviour have been carried out in New Zealand (reviewed in Clapperton and Byrom 2005). Although these studies have consistently shown rabbits Oryctolagus cuniculus to be an important dietary component 
(Murphy et al. 2004; Clapperton and Byrom 2005), ferrets are opportunistic predators (Smith et al. 1995), and their diet may vary according to the availability of prey. Consequently, they have been demonstrated to be a threat to a variety of ground and burrow nesting birds including shorebirds (Dowding and Murphy 2001; Keedwell et al. 2002) and seabirds (Alterio and Moller 1997; Lyver 2000). These threats have been shown to increase markedly following declines in rabbit availability after outbreaks of rabbit haemorrhagic disease (RHD). This occurs because ferrets switch to alternative prey in the short term, in order to avoid starvation (Norbury et al. 1998; Rebergen et al. 1998; Norbury 2001). While predator populations may eventually decline if prey availability remains low, the reproductive strategies of alternative prey species such as shorebirds (Rebergen et al. 1998) or reptiles (Norbury 2001) may not enable these populations to withstand even a short-term increase in predation levels.

Although exotic predators can in isolation have severe consequences for native species, their impact is often exacerbated when introduced prey species are also present. This can lead to hyperpredation (Courchamp et al. 1999), where predator populations eat introduced prey and can increase substantially above the level that could be sustained by the native prey base alone. For example, the Macquarie Island parakeet Cyanoramphus erythrotis coexisted with small feral cat populations for over 70 years, but the later introduction of rabbits provided a higher yearround food supply, allowed the cat population to increase, and resulted in the rapid extinction of the parakeet (Taylor 1979). Introduced mammalian prey are present on most UK islands (Harris and Yalden 2008), and ferrets are also known to be effective scavengers (Ragg et al. 2000), so there is the potential for such exogenous prey resources to subsidise ferret populations, particularly over winter, and thereby increase the threat to native species.

A number of feral ferret populations exist in the British Isles (Kitchener and Birks 2008), although there are few records of self-sustaining mainland populations, with most appearing to be lost working animals or escapees (Birks 2008; Kitchener and Birks 2008). Similarly, despite having been present for at least 20 years in the Irish border counties, the feral ferret population in this region appears to have spread very little (Buckley et al. 2007). Small mustelids are frequently killed and sometimes eaten by other, larger carnivores (Korpimäki and Norrdahl 1989; Donadio and Buskirk 2006) and must also compete with other guild members (Erlinge and Sandell 1988; McDonald 2002). Because ferrets are feral rather than truly wild animals (Kitchener and Birks 2008), they are less wary and exhibit reduced levels of aggression compared to their wild ancestor the European polecat Mustela putorius (Poole 1972). Thus, the presence of predators and competitors is likely to prevent released/escaped individuals forming persistent mainland populations, and feral ferrets tend to be found on islands where other predators are scarce or absent (Kitchener and Birks 2008). As many of these islands support internationally important breeding bird populations (Fuller et al. 1986; Mitchell et al. 2004), ferrets may pose a significant conservation threat.

Here, we investigate the diet and bioenergetics of feral ferrets on Rathlin Island, UK, to quantify their impacts and gain an understanding of the threat posed by this introduced predator, with varying population sizes of introduced prey. The relative importance of different resources particularly over winter, when natural mortality might ordinarily be higher, can then identify suitable conservation management strategies, which will be explored, and may be employed to reduce predator populations and so mitigate conservation and ethical conflicts.

\section{Materials and methods}

\section{Study area}

Rathlin Island $\left(55^{\circ} 18^{\prime} \mathrm{N} 06^{\circ} 13^{\prime} \mathrm{W} ; 1525\right.$ ha) is situated just over $3 \mathrm{~km}$ off the northeast coast of Northern Ireland. The vegetation is dominated by acid grassland and maritime heath, with small ponds, flushes, and wetlands. The island has a year-round population of approximately 85 people and has been inhabited since Neolithic times. Ferrets were introduced in multiple releases in the mid 1980s (L. McFaul, personal communication) in an attempt to control the introduced rabbit population. A number of small mammalsbrown rat Rattus norvegicus, Eurasian pygmy shrew Sorex minutus, wood mouse Apodemus sylvaticus, and house mouse Mus musculus - have also been introduced at various and unknown times. Most land is grazed by livestock at low stocking densities. Internationally important populations of common guillemot Uria aalge, razorbill Alca torda, and black-legged kittiwake Rissa tridactyla are present throughout the breeding season along more than $15 \mathrm{~km}$ of coastline (Mitchell et al. 2004), and the island is designated for protection under a number of conservation instruments.

\section{Scat collection and prey identification}

Scats were collected from animals caught in live traps, from outside the resting sites of radio-collared individuals, and when found while pursuing other fieldwork. When preserved fish bait had been consumed in live traps, these scats were discarded. This constituted less than $3 \%$ of capture events. Gut passage time in small mustelids is rapid (Short 1961; Sibbald et al. 1962), and this means that even multiple meals taken from one large prey item will be 
processed rapidly. However, scats were collected only on the first day from any individuals trapped on successive days to ensure larger prey items were not overrepresented. While scats were also collected on an ad hoc basis, which may inevitably lead to a degree of nonindependent sampling, they were not collected from the same locations on consecutive days, and they were collected throughout the island so there is no reason to assume they do not represent a broad range of individuals. Scats were collected throughout the island during ferret population monitoring between October and February in 2005 to 2006 and 2006 to 2007 and while monitoring nesting birds between March and July in 2006 and 2007. Fieldwork was not carried out in August or September.

Scats were broken down in water and passed through sieves of 1000,500 , and $106 \mu \mathrm{m}$. The remaining residue for a subsample of 20 scats was checked for the presence of microscopic remains such as earthworm chaetae (Reynolds and Aebischer 1991), but as none were found, this was not investigated further. The material was sorted under a lowpower $(\times 10)$ dissection microscope to identify guard hairs and feather remains and other body parts. These were then identified to species or order following the methods of Teerink (1991) and Day (1966). Hare and rabbit hairs were distinguished following the methods of Wolfe and Long (1997). Any vegetation found was excluded from analyses. As it was impossible to distinguish between hunted and scavenged items, all remains are referred to as prey with the exception of those from large ungulates, which are termed carrion throughout. As ferret hairs were not found in large quantities in any scats, they were assumed to have been consumed accidentally, for example, during grooming, and so were disregarded (Day 1968).

A subsample of 30 scats was examined closely, and hair from only one potential mammal prey species was found within any individual scat. As scats are small compared to the size of many potential prey items, this suggests that one scat represents either one complete prey item or the remains of one feeding session from a larger species (Day 1968; McDonald et al. 2000). However, different prey types can have different passage times within the mustelid gut (Short 1961; Sibbald et al. 1962) and remains such as eggshell fragments, beetle elytra, feathers, and, occasionally, livestock hairs were sometimes found alongside mammalian remains in the same scat. As such, these scats were considered to reveal the earlier consumption of two separate prey items, so all prey remains were considered as separate items for the purposes of dietary analysis. It is possible for an animal to accidentally ingest a single feather or hair and so a conservative approach was taken, with these remains only included as prey items when multiple examples were found alongside mammalian hair within a single scat.
Dietary analysis and prey consumption

In common with previous studies of ferrets and other carnivores (e.g., Smith et al. 1995; Ragg 1998; van Dijk et al. 2007), food items are presented here as frequency of occurrence, i.e., the number of scats containing a food item. In addition, the percentage frequency of occurrence, i.e., the percentage of the total number of identifiable prey items, is presented as it represents the minimum number of prey items eaten (McDonald et al. 2000). Food items were placed into eight categories based on similarity of digestion and/or size: lagomorphs, rats, small mammals, invertebrates, birds, eggs, sheep carrion, and cattle carrion. The latter two were separated because of the large discrepancy in carcass weights and thus potential available meals.

Niche overlap between the sexes and years was calculated using Pianka's measure (Pianka 1973), and as patterns were consistent between years, data were combined. Radio telemetry revealed that multiple animals used the same resting sites either simultaneously or consecutively (T. Bodey, unpublished data); thus, only those scats collected from trapped individuals were used to compare diets between the sexes as a scat outside a resting place may have come from one of several individual ferrets. Niche breadth was calculated using Levins's adaptation of the Simpson diversity index (Levins 1968) and was standardised according to Krebs (1999). Bootstrapping of dietary parameters, as recommended by Reynolds and Aebischer (1991), was undertaken using Gibbs sampling of Markov chain Monte Carlo using a binary model in Winbugs (version 3.0.2) with 300,000 iterations after a burn-in of 10,000 iterations. Ninety-five percent credibility intervals were generated for the percentage frequency of occurrence of prey items and for niche breadth.

\section{Bioenergetics model}

The total quantity of prey required to support the ferret population was calculated for the 'autumn-winter' period from October to February. Although scats were also collected during the 'spring-summer' period from March to July, a similar value was not calculated for this time because of the limited sample size (a result of the demands of other fieldwork examining the breeding performance of ground-nesting birds) and the additional assumptions required to estimate energy requirements in a breeding population. The field metabolic rate (FMR) of a ferret was calculated using the equation for all mammals from Nagy $(2005)$ as FMR $=4.82^{*}$ (body mass in grams) $)^{0.734}$. Capturemark-recapture studies were carried out on the island, and data from these were used to calculate both mean ferret body mass ( $n=100$ animals, T. Bodey, unpublished data) and population size using Lincoln-Peterson estimators (Chapman 1951). The latter was averaged over the 2 years 
to obtain a whole island population estimate, enabling calculation of the population's energy requirements.

The total energy requirement was apportioned according to the identified percentage frequencies of occurrence of prey categories within scats, and this was converted to the number of animals consumed. To examine the potential impact on alternative prey following a reduction in primary prey, we calculated similar values based on the maximal $33 \%$ decline in the rabbit (taken as lagomorph) population found following recent severe myxomatosis outbreaks in the UK (Trout et al. 1992). Increases in secondary prey consumption were taken at consistent proportions to those initially found in scats.

Energy content per gram of dry weight (g dry wt) and metabolizable and dry weight percentages for prey groups were located in the literature, with an emphasis on studies using either mustelids (Moors 1977; Davison et al. 1978; Powell et al. 1985) or other carnivores (Litvaitis and Mautz 1976, 1980; Konecny 1987; Powers et al. 1989; Aldama et al. 1991; Ahlstrøm and Skrede 1995, 1998; Williams et al. 1997), plus additional information on birds and eggs (Sotherland and Rahn 1987; Votier et al. 2004). All wet weights were converted to dry weights at $30 \%$ as a mean of study values, and average prey-specific values were taken as studies reported either broadly or highly similar values.

At $3400 \mathrm{~g}$, the mean weight of Irish hares (Iason et al. 2008 ) is considerably greater than the 1600 -g median value for rabbits (Cowan and Hartley 2008). However, given the much greater preponderance of rabbits both within ferret diet and on the island itself, a value of $1600 \mathrm{~g}$ was taken for all lagomorphs but was reduced by $25 \%$ to $1200 \mathrm{~g}$ to account for unconsumed skeletal components. As ferrets will only consume edible parts of a large carcass, boneless weights of sheep and cattle were conservatively estimated at $20 \mathrm{~kg}$ (Newton et al. 1982) and $350 \mathrm{~kg}$ (Hall and Putman 2008), respectively. A comprehensive survey of livestock carcasses was undertaken over the entire island while carrying out radio telemetry fieldwork. Almost all invertebrate remains were from coleopterans, and an average weight of $1.5 \mathrm{~g}$ was assumed per beetle (Kowalski et al. 1999). Rats were split from other small mammals with calculations for the former based on a brown rat weight of $300 \mathrm{~g}$ (Quy and Macdonald 2008). Pygmy shrews and wood mice were combined into a small mammal category, and a weight value of $10 \mathrm{~g}$ was used based on the proportional representation of the two species in scats (Churchfield and Searle 2008; Flowerdew and Tattersall 2008). Based on fragment size and shape, eggshell was assumed to be from cached seabird eggs as no species breed over winter, so an average of the weight of the three principal breeding species on Rathlin - common guillemot, razorbill, and black-legged kittiwake - was taken (Sotherland and Rahn 1987), producing a value of $80 \mathrm{~g}$.
Mean bird weight was derived using principal orders identified in scats, and then the most frequently observed species from these orders on Rathlin, i.e., ring-necked pheasant Phasianus colchicus, mallard Anas platyrhynchos, common pochard Aythya ferina, and tufted duck Aythya fuligula (Snow and Perrins 1994; T. Bodey, personal observation), producing a value of $990 \mathrm{~g}$. As literature values for metabolizable energy from bird carcasses already included a correction for indigestible components (e.g., Votier et al. 2004), this value was not reduced to exclude inedible components.

Sensitivity analysis

There was only limited description in the literature of the variation in the input parameters to the consumption model. Therefore, the sensitivity of the outputs of the model to variation in the input parameters was tested by changing the prey energetic parameter values by \pm one standard deviation (SD) and recalculating the outputs. Similarly, the mean weight of ferrets, and the percentage of occurrence, was varied by \pm one $\mathrm{SD}$, with the latter values obtained from the Gibbs bootstrap sampling outlined in the dietary analysis above. The estimate of ferret population was altered by $\pm 20 \%$, reflecting known variation in numbers (T. Bodey, unpublished data). As published values of prey weights did not contain associated SDs, and because changes in \% weight would simply have had linear effects on the quantities of prey consumed (i.e., a $10 \%$ increase in weight would lead to a $10 \%$ decrease in prey required), such values were not included in the sensitivity analysis.

\section{Results}

\section{Dietary analysis}

A total of 267 scats contained identifiable remains out of 274 scats collected (Table 1): 92 were collected during the 2005 to 2006 field seasons ( 75 autumn-winter, 18 springsummer), with 32 assignable to individuals (11 male, 7 female), and 182 (157 autumn-winter, 24 spring-summer) from the 2006 to 2007 seasons with 76 from known animals (21 male, 11 female). Lagomorphs occurred in $83 \%$ of all scats, of which rabbits, at $75 \%$, comprised the majority of prey. Bird remains in the form of feathers and eggshell (11\%), and small mammals (11\%) were important secondary prey items. Carrion in the form of livestock was also an important food source $(11 \%)$, with a minor role for invertebrates.

Diet changed little between study years (Fig. 1a). Levins's measure of niche breadth varied little between 
Table 1 Representation of prey items in the diet of feral ferrets on Rathlin Island
Results of the examination of the prey remains in ferret scats collected between October 2005 to July 2007. Major taxonomic groupings are highlighted in bold, and bootstrapped credibility intervals are included to reflect estimates of the variability in sampling errors

\begin{tabular}{lll}
\hline Prey item & $\begin{array}{l}\text { Frequency of } \\
\text { occurrence in scats }\end{array}$ & $\begin{array}{l}\text { Percentage frequency of occurrence } \\
(95 \% \text { credibility interval) }\end{array}$ \\
\hline Mammals & $\mathbf{2 8 3}$ & $\mathbf{8 7 . 1}(\mathbf{8 3 . 0}-\mathbf{9 0 . 3})$ \\
O. cuniculus & 199 & $61.2(55.8-66.4)$ \\
Lepus timidus & 23 & $7.1(4.8-10.4)$ \\
R. norvegicus & 24 & $7.4(5.0-10.8)$ \\
S. minutus & 4 & $1.2(0.5-3.1)$ \\
A. sylvaticus & 1 & $0.3(0.1-1.7)$ \\
Unidentified bone fragments & 3 & $0.9(0.1-2.7)$ \\
Ovis aries & 14 & $4.3(2.6-7.1)$ \\
Bos taurus & 15 & $4.6(2.8-7.5)$ \\
Birds & $\mathbf{3 0}$ & $\mathbf{7 . 4}(\mathbf{5 . 0}-\mathbf{1 0 . 8})$ \\
Anseriformes & 8 & $2.5(1.3-4.8)$ \\
Galliformes & 5 & $1.5(0.7-3.5)$ \\
Charadriiformes & 3 & $0.9(0.3-2.7)$ \\
Ralliformes & 2 & $0.6(0.2-2.2)$ \\
Passeriformes & 2 & $0.6(0.2-2.2)$ \\
Unidentified feathers & 4 & $1.2(0.5-3.1)$ \\
Birds' eggs & 6 & $1.8(0.9-4.0)$ \\
Invertebrates & $\mathbf{1 2}$ & $\mathbf{3 . 7}(\mathbf{2 . 1}-\mathbf{6 . 3 )}$ \\
Coleoptera & 11 & $3.4(1.9-6.0)$ \\
Mytilus edulis & 1 & $0.3(0.1-1.6)$ \\
Total no. of identified prey items & 325 & 100 \\
No. of scats containing only & 7 & \\
$\quad$ unidentifiable items & & \\
No. of scats containing ferret hair & 15 & \\
\hline & & \\
Total no. of scats examined & & \\
\hline
\end{tabular}

years or seasons, although there is a suggestion that males may have a broader dietary niche than females (Table 2), consuming fewer lagomorphs and carrion but with an increased take of birds and small mammals (Fig. 1b). However, these differences are small, and this is reflected in the almost complete dietary overlap between years, sexes, and between autumn-winter and spring-summer diet (Table 2).

\section{Bioenergetics model}

Mean ferret mass $\pm \mathrm{SD}$ was $1070 \pm 370 \mathrm{~g}(n=100)$, yielding an FMR of $800 \mathrm{~kJ}$ day $^{-1}$, and for the entire autumn-winter period, an energy requirement of $122000 \mathrm{~kJ}$ per ferret. Mean population size \pm SE over the 2 years was $54 \pm 11$ individuals, giving a population energy requirement of 6600 MJ for each of the 5-month periods. Based on percentage frequency of occurrence, the ferret population consumes considerable numbers of birds, eggs, invertebrates, and small mammals in addition to their main lagomorph prey (Table 3). However, scat remains suggest they consume relatively few carcasses in proportion to their availability on the island (sheep: $2006 n_{\text {carcasses }}=15$, representing a potential $2025 \mathrm{MJ}$ of metabolizable energy; $2007 n_{\text {carcasses }}=17,2295 \mathrm{MJ}$; cattle: $2006 n_{\text {carcasses }}=2$, $\left.4730 \mathrm{MJ} ; 2007 n_{\text {carcasses }}=1,2360 \mathrm{MJ}\right)$. A hypothetical reduction of one third in lagomorph availability led to an approximate doubling in the amount of secondary prey required for all groups if proportional consumption remained the same (Table 3).

Sensitivity analysis

Given the simple nature of the equation, it is perhaps unsurprising that potential variation in input values led to substantial effects on the estimated prey requirements of the ferret population (Table 4). This is particularly the case given the known variation in ferret population size between years and the large SD associated with body mass resulting from significant intrasexual differences in body size. Variables associated with prey calorific content had least impact, reflecting the broad agreement within the literature. Potential extreme values for percentage occurrence of lagomorphs had little overall effect, whereas large variations were found for minor prey components. 
a

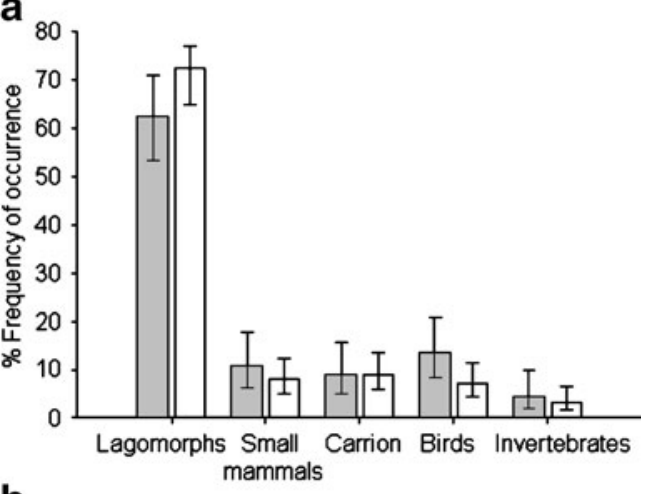

b

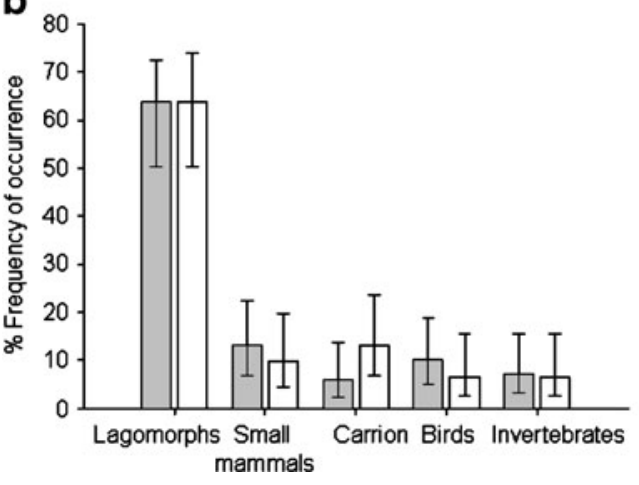

Fig. 1 The percentage frequency of occurrence of all prey items found in ferret scats categorised by species groups for study years (a): Oct 2005 to Jul 2006 (grey bars, $n=92$ ) and Oct 2006 to Jul 2007 (white bars, $n=182$ ), and sexes $(\mathbf{b})$ : male (grey bars, $n=60$ ) and female (white bars, $n=48$ ). Error bars represent $95 \%$ Bayesian credibility intervals

\section{Discussion}

Dietary analysis and prey consumption

Ferret diet appeared to vary little with time or between the sexes, with only minor differences in dietary niche width and almost complete dietary overlap despite including a range of prey types (Table 2, Fig. 1). Although there may still be variation in size of rabbits taken with males consuming more adults, and females more nestlings and juveniles (Ragg 1998), too few claws and teeth were found in scats to enable such comparisons to be made in our study. Studies from New Zealand have suggested some degree of difference between the sexes (Ragg 1998), while others found no difference or only minor differences (Mills 1994; Murphy et al. 2004), the latter a finding mirrored in the polecat in Europe (Lode 2003). The lower occurrence of avian remains in scats in both seasons suggests that predation on birds is incidental, with ferrets continuing to seek out preferred lagomorph prey. Indeed, the diet of both the ferret in New Zealand (Clapperton and Byrom 2005) and the polecat across Europe (Lode 1997) is relatively uniform, with rabbits often remaining an important prey item even when they are relatively uncommon (Blandford 1987).

While it is known that scat analysis contains biases in the detection of some prey items (Reynolds and Aebischer 1991), few, if any, soft-bodied prey species were available to ferrets, so this is unlikely to be a problem in this study. However, it may be that items such as carrion, eggs (presumably reflecting the consumption of cliff-nesting seabird eggs cached by corvids during the previous breeding season), and birds are underrepresented as ferrets may not consume large quantities of indigestible material from these sources. Mammalian predators may lick out the contents of eggs rather than consuming them whole (Green et al. 1987); birds may be skinned so that few feathers are consumed (Cuthbert 2003) and feathers may become less identifiable after digestion (Reynolds and Aebischer 1991). It is also unlikely that, after opening a livestock carcass, much hide (and thus hair) would be consumed, particularly by animals feeding inside the body cavity (Reynolds and Aebischer 1991; T. Bodey, personal observation). However, the frequency of occurrence of secondary prey items is comparable with studies of ferrets in New Zealand with similar prey availability (Smith et al. 1995; Ragg 1998), supporting the overall prey consumption ratio identified here.

Table 2 Dietary niche breadth of feral ferrets on Rathlin Island

\begin{tabular}{llllr}
\hline Group & $n$ & $B$ & 95 percentile range, confidence interval & $B_{\mathrm{A}}$ \\
\hline All ferrets & 325 & 2.66 & $2.26-3.14$ & 0.15 \\
All males & 72 & 3.34 & $2.21-4.74$ & 0.21 \\
All females & 62 & 2.76 & $1.88-4.02$ & 0.16 \\
$2005-2006$ & 119 & 2.96 & $2.20-3.92$ & 0.18 \\
$2006-2007$ & 216 & 2.48 & $2.05-3.03$ & 0.13 \\
Oct-Feb & 291 & 2.68 & $2.24-3.21$ & 0.15 \\
Mar-Jul & 44 & 2.37 & $1.59-3.62$ & 0.984 \\
\end{tabular}

Levins's measure of dietary niche breadth $(B)$ with bootstrapped credibility interval estimates of the variability in sampling errors; standardised Levins's measure $\left(B_{\mathrm{A}}\right)$; and Pianka's measure of niche overlap $(O)$ between the sexes, years, and seasons, calculated from all prey items found in ferret scats. $n$ is the number of items in the scats examined, with only those collected from known individuals or on known dates included where appropriate 


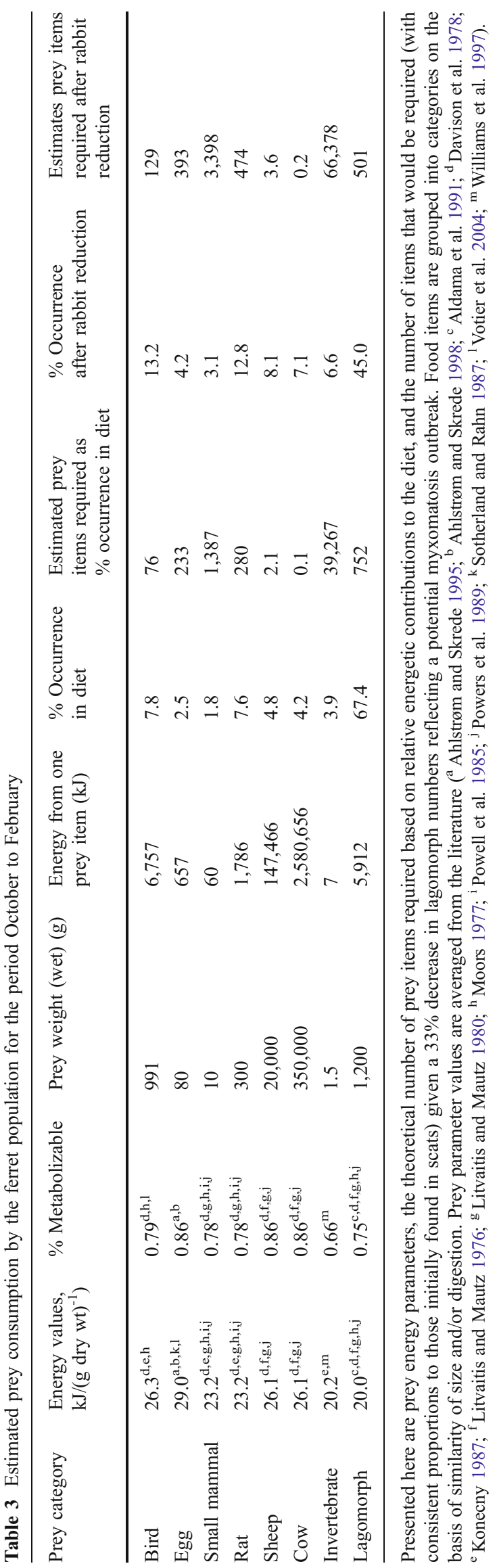

Bioenergetics model performance

As with all bioenergetics models, there are a number of potential biases as a result of errors in the estimation of parameter values, and some of these are magnified by the simplicity of the model presented here. The large variation in numbers of prey required with extreme values of ferret weight, and so FMR, is largely a result of the substantial size variation that is common to all small mustelids (Moors 1980). Although the smaller females will have lower energetic demands than males over winter, any reductions are likely to be compensated for by substantially increased demands during the breeding season (Powell and Leonard 1983). Extreme values for percentage occurrence of minor prey items also produced greater variation than for lagomorph prey, reflecting the greater proportional difference such variation makes to smaller numbers, as well as the greater degree of uncertainty associated with infrequently observed prey items. Values for invertebrates, shrews, and mice appear to be overestimated, but population sizes of all mammals other than ferrets remain unquantified, and this study suggests that such prey items, and the impact the ferret population can have on them, should not be ignored. Extreme values of ferret population size led to wide variation in prey consumed. This demonstrates that impacts on prey, particularly species of conservation concern, may need to be considered over multiple years to accurately assess the risk posed by a ferret population, which may fluctuate in size.

\section{Conservation management implications}

All islands in the UK on which there are feral ferret populations also support introduced rabbits, and given the high prevalence of rabbits in ferret diet, this strongly suggests that such introduced prey may not only be a potential cause of hyperpredation (Courchamp et al. 1999) but also is, in fact, key to the establishment and maintenance of ferret populations. In New Zealand, ferret population dynamics have been shown to be linked to rabbit numbers (Barlow and Norbury 2001), and severe reductions in rabbit availability through poisoning or disease can have dramatic impacts on ferret behaviour. For example, the release of RHD has had important effects on conservation management as near absence of rabbits after initial disease outbreaks resulted in increased itinerancy amongst animals (Norbury et al. 1998) and in significant diet switching to often highly endangered secondary prey (Murphy et al. 2004; Norbury and Heyward 2008). While this ability to switch to alternatives can cushion a predator population against reductions in their principal prey, the negative effects for alternative prey species are often severe (Sinclair et al. 1998).

In the long term, a decline in prey will lead to a decline in the predator population. However, for the secondary prey 
Table 4 Sensitivity analysis for the prey consumption model

\begin{tabular}{|c|c|c|c|}
\hline \multicolumn{2}{|l|}{ Parameter } & Range of parameter extremes & $\%$ Change in output at parameter extremes \\
\hline Population size & & $\pm 20 \%$ & $-16.7,+25.0$ \\
\hline $\operatorname{FMR}\left(\mathrm{kJ}\right.$ day $\left.^{-1}\right)$ & & \pm 1 SD of ferret weight & $-19.7,+36.9$ \\
\hline Dry weight of prey (\%) & & $\pm 1 \mathrm{SD}$ & \pm 10.5 \\
\hline Metabolizable (\%) & & $\pm 1 \quad \mathrm{SD}$ & $-3.8,+6.4$ \\
\hline \multirow[t]{8}{*}{ Calorific value of prey $\left(\mathrm{kJ}[\mathrm{g} \text { dry } \mathrm{wt}]^{-1}\right)$} & Bird & $\pm 1 \quad \mathrm{SD}$ & \pm 6.4 \\
\hline & Egg & $\pm 1 \quad \mathrm{SD}$ & \pm 3.8 \\
\hline & Small mammal & $\pm 1 \quad \mathrm{SD}$ & \pm 9.0 \\
\hline & Rat & $\pm 1 \quad \mathrm{SD}$ & \pm 9.0 \\
\hline & Sheep & $\pm 1 \quad \mathrm{SD}$ & \pm 4.2 \\
\hline & Cow & $\pm 1 \quad \mathrm{SD}$ & \pm 4.2 \\
\hline & Invertebrate & $\pm 1 \quad \mathrm{SD}$ & \pm 19.8 \\
\hline & Lagomorph & $\pm 1 \quad \mathrm{SD}$ & \pm 3.0 \\
\hline \multirow[t]{8}{*}{$\%$ Occurrence in diet } & Bird & $\pm 1 \quad \mathrm{SD}$ & $-9.0,+25.9$ \\
\hline & Egg & $\pm 1 \quad \mathrm{SD}$ & $-49.4,+27.2$ \\
\hline & Small mammal & $\pm 1 \mathrm{SD}$ & $-45.0,+17.7$ \\
\hline & Rat & $\pm 1 \mathrm{SD}$ & $-11.8,+24.3$ \\
\hline & Sheep & $\pm 1 \quad \mathrm{SD}$ & $-30.8,+23.2$ \\
\hline & Cow & $\pm 1 \quad \mathrm{SD}$ & $-14.6,+32.7$ \\
\hline & Invertebrate & $\pm 1 \quad \mathrm{SD}$ & $-60.0,+15.7$ \\
\hline & Lagomorph & $\pm 1 \quad \mathrm{SD}$ & $-3.0,+5.0$ \\
\hline
\end{tabular}

The percentage changes in output reflect either the population energy requirement (for population size, FMR, dry weight of prey, and metabolizable percentage) or the number of prey animals required from a specific group (for calorific value and percentage occurrence) at maximum and minimum input parameters.

that has high adult survival and/or low reproductive effort such as seabirds and shorebirds (Snow and Perrins 1994), even a short-term increase in predation may have severe long-term population consequences and, particularly on a small island, can rapidly result in extirpation (Taylor 1979; Mitchell et al. 2004). Thus, the combined presence of rabbits and ferrets on Rathlin may be at least partly responsible for the reductions in the numbers of breeding puffins Fratercula arctica and gulls Larus spp. (Anonymous 2007) and extirpation of Manx shearwater Puffinus puffinus (L. McFaul, personal communication). This is certainly consistent with the demonstrated impacts of ferrets on numerous similar ground-nesting species in New Zealand (Alterio and Moller 1997; Rebergen et al. 1998; Dowding and Murphy 2001; Murphy et al. 2004). Such evidence needs to be considered when assessing the threat posed by feral ferrets in the UK. For example, it will be important to monitor ferrets in the Uists, Outer Hebrides, as, assuming American mink eradication is ultimately successful (Roy 2006; Bodey et al. 2010), they will then be the top terrestrial predator on these islands.

On Rathlin, the rabbit population suffers from sporadic myxomatosis outbreaks (R. Green, personal communication), and so reductions in rabbit availability may be expected to similarly affect ferret populations here. Although such out- breaks do not have the same decimating impact on rabbit populations as seen with eruptions of RHD in Australia and New Zealand, it is clear that, for the ferret population to persist at pre-outbreak levels, substantial additional secondary prey would need to be consumed (Table 3). Given the low numbers of many accessible bird species currently present on Rathlin (Anonymous 2007; L. McFaul, unpublished data), a doubling in the number consumed shows the potentially serious impact ferrets could have if prey switching occurred. Although ferret predation on birds may be incidental, such threats assume greater proportional significance on small populations (Caughley 1994). In addition, ferrets have been present on Rathlin for over 20 years prior to the initiation of this study, and therefore, any initial impacts may no longer be apparent (Strayer et al. 2006), or our smaller summer sample sizes may not have accurately reflected consumption of birds during this period. Equally, ferrets may switch to carrion as it is simple to access. While this will not increase immediate losses to bird populations, it does mean that the predator population, and thus its impact on avian species, will be sustained despite declines in primary prey. Thus, the presence of carrion, effectively an extra prey resource, may prevent either a natural decline or management of rabbit numbers from allowing ferrets and avian prey to establish equilibrium (Sinclair et al. 1998). 
Both the theoretical and practical examination of hyperpredation is typically based on uninhabited islands (Courchamp et al. 1999; Roemer et al. 2002), and such places often have limited or no anthropogenic food sources available. However, such resources can support increased predator numbers (Fedriani et al. 2001; Boarman 2003; Quinn and Whisson 2005), and, on Rathlin, available livestock carrion would be sufficient to meet the entire ferret population's energy requirements alongside only a small quantity of other prey. Numerous individuals were tracked using radio telemetry to denning sites in close proximity to, or were actively feeding upon, carcasses (T. Bodey, personal observation, M Ruddock, personal communication), and multiple individuals will consume even small carcasses simultaneously (Ragg et al. 2000). Such anthropogenic food sources can thus create an additional threat to endangered prey populations (Fedriani et al. 2001; Boarman 2003) and further complicate management decisions.

Increasingly, it is recognised that management of both predators and prey may be necessary to achieve conservation objectives (Courchamp et al. 2003b). Management on Rathlin could beneficially tackle the combination of ferrets, rabbits, and carrion. The latter is clearly the most straightforward, although not without difficulties on a rugged island. Burial of carcasses might be of limited impact given the digging capabilities of ferrets. However, addressing such issues as the accidental or deliberate provision of supplemental food has potential as a method for reducing incidental predation on vulnerable avian populations in this case, and similarly on other inhabited islands. Direct removal of any combination of ferrets, rabbits, and also rats to avoid the potential for mesopredator release (Soulé et al. 1988) is a potential longer term ambition but is more logistically demanding. The recent successful eradication of brown rats from the topographically similar and comparably sized island of Canna in Scotland (Luxmore 2008) demonstrates the feasibility of this approach. However, community involvement and education would be essential to ensure any such effort was successful given Rathlin's larger population and increased number of stakeholders. Wider public engagement and the provision of suitable quarantine facilities would also be a prerequisite to ensure against reinvasion given multiple daily car ferries, the transportation of many hundreds of tourists and building materials, and the mooring of private boats. However, these are not insurmountable, and the potential conservation benefits suggest such actions should be carefully evaluated.

Acknowledgements TWB was supported by a Ph.D. studentship through the Quercus partnership between Northern Ireland Environment Agency and Queen's University, Belfast. We are grateful to the residents and landowners of Rathlin for providing access throughout the study site, to Rosalind Kennerley and Jonathan Reeves for assistance with fieldwork, and to the veterinary staff at the Agri-Food and Biosciences
Institute, Belfast, for carrying out post mortems. We thank two anonymous reviewers for their helpful comments.

All animal procedures were carried out under Home Office Licence, and all experimental fieldwork was approved by the Queen's University Belfast ethics committee.

\section{References}

Ahlstrøm O, Skrede A (1995) Comparative nutrient digestibility in blue foxes (Alopex lagopus) and mink (Mustela vison) fed diets with diverging fat/carbohydrate ratios. Acta Agric Scand A 45:74-80

Ahlstrøm O, Skrede A (1998) Comparative nutrient digestibility in dogs, blue foxes, mink, and rats. J Nutr 128:2676S-2677S

Aldama JJ, Beltran JF, Delibes M (1991) Energy-expenditure and prey requirements of free-ranging Iberian lynx in southwestern Spain. J Wildl Manag 55:635-641

Alterio N, Moller H (1997) Daily activity of stoats (Mustela erminea), feral ferrets (Mustela furo) and feral house cats (Felis catus) in coastal grassland, Otago Peninsula, New Zealand. New Zeal J Ecol 21:89-95

Anonymous (2007) Rathlin seabird colony survey 2007. Allen \& Mellon Environmental Ltd., UK

Atkinson I (1989) Introduced animals and extinctions. In: Western D, Pearl MC (eds) Conservation for the twenty first century. Oxford University, Oxford, pp 54-75

Barlow ND, Norbury GL (2001) A simple model for ferret population dynamics and control in semi-arid New Zealand habitats. Wildl Res 28:87-94

Birks JDS (2008) The Polecat Survey of Britain 2004-2006: a report on the Polecat's distribution, status and conservation. The Vincent Wildlife Trust, London

Blackburn TM, Cassey P, Duncan RP, Evans KL, Gaston KJ (2004) Avian extinction and mammalian introductions on oceanic islands. Science 305:1955-1958

Blandford PRS (1987) Biology of the polecat Mustela putorius-a literature review. Mamm Rev 17:155-198

Boarman WI (2003) Managing a subsidized predator population: reducing common raven predation on desert tortoises. Environ Manag 32:205-217

Bodey TW, Bearhop S, Roy SS, Newton J, McDonald RM (2010) Behavioural responses of invasive American mink Neovison vison to an eradication campaign, revealed by stable isotope analysis. J Appl Ecol 47:114-120

Buckley DJ, Sleeman DP, Murphy J (2007) Feral ferrets Mustela putorius furo L. in Ireland. Ir Nat J $28: 356-360 \mathrm{v}$

Caley P, Hone J (2005) Assessing the host disease status of wildlife and the implications for disease control: Mycobacterium bovis infection in feral ferrets. J Appl Ecol 42:708-719

Caughley G (1994) Directions in conservation biology. J Anim Ecol 63:215-244

Chapman DG (1951) Some properties of the hypergeometric distribution with applications to zoological censuses. Univ Calif Publ Stat 1:131-160

Churchfield S, Searle JB (2008) Pygmy shrew. In: Harris S, Yalden DW (eds) Mammals of the British Isles: handbook, 4th edn. The Mammal Society, Southampton, UK, pp 267-271

Clapperton BK, Byrom A (2005) Feral ferret. In: King CM (ed) The handbook of New Zealand mammals, 2nd edn. Oxford University, Melbourne, Victoria, pp 294-308

Courchamp F, Langlais M, Sugihara G (1999) Control of rabbits to protect island birds from cat predation. Biol Conservat 89:219 225

Courchamp F, Chapuis JL, Pascal M (2003a) Mammal invaders on islands: impact, control and control impact. Biol Rev 78:347-383 
Courchamp F, Woodroffe R, Roemer G (2003b) Removing protected populations to save endangered species. Science 302:1532-1532

Cowan DP, Hartley FG (2008) Rabbit. In: Harris S, Yalden DW (eds) Mammals of the British Isles: handbook, 4th edn. The Mammal Society, Southampton, UK, pp 201-210

Cuthbert R (2003) Sign left by introduced and native predators feeding on Hutton's shearwaters Puffinus huttoni. New Zeal J Zool 30:163-170

Davison RP, Mautz WW, Hayes HH, Holter JB (1978) Efficiency of food utilization and energy-requirements of captive female fishers. J Wildl Manag 42:811-821

Day MG (1966) Identification of hair and feather remains in gut and faeces of stoats and weasels. J Zool 148:201-217

Day MG (1968) Food habits of British stoats (Mustela erminea) and weasels (Mustela nivalis). J Zool 155:485-497

Donadio E, Buskirk SW (2006) Diet, morphology, and interspecific killing in carnivora. Am Nat 167:524-536

Dowding JE, Murphy EC (2001) The impact of predation by introduced mammals on endemic shorebirds in New Zealand: a conservation perspective. Biol Conservat 99:47-64

Erlinge S, Sandell M (1988) Coexistence of stoat, Mustela erminea, and weasel, Mustela nivalis - social-dominance, scent communication, and reciprocal distribution. Oikos 53:242-246

Fedriani JM, Fuller TK, Sauvajot RM (2001) Does availability of anthropogenic food enhance densities of omnivorous mammals? An example with coyotes in southern California. Ecography 24:325-331

Flowerdew JR, Tattersall FH (2008) Wood Mouse. In: Harris S, Yalden DW (eds) Mammals of the British Isles: handbook, 4th edn. The Mammal Society, Southampton, UK, pp 125-137

Fuller RJ, Reed TM, Buxton NE, Webb A, Williams TD, Pienkowski MW (1986) Populations of breeding waders Charadrii and their habitats on the crofting lands of the Outer Hebrides, Scotland. Biol Conservat 37:333-361

Green RE, Hawell J, Johnson TH (1987) Identification of predators of wader eggs from egg remains. Bird Study 34:87-91

Hall SJG, Putman RJ (2008) Cattle. In: Harris S, Yalden DW (eds) Mammals of the British Isles: handbook, 4th edn. The Mammal Society, Southampton, UK, pp 634-637

Harris S, Yalden DW (2008) Mammals of the British Isles: handbook, 4th edn. The Mammal Society, Southampton, UK

Iason GR, Hulbert IAR, Hewson R, Dingerkus K (2008) Mountain Hare/Irish Hare. In: Harris S, Yalden DW (eds) Mammals of the British Isles: handbook, 4th edn. The Mammal Society, Southampton, UK, pp 220-228

Jones HP, Tershy BR, Zavaleta ES, Croll DA, Keitt BS, Finkelstein ME, Howald GR (2008) Severity of the effects of invasive rats on seabirds: a global review. Conservat Biol 22:16-26

Keedwell RJ, Maloney RF, Murray DP (2002) Predator control for protecting kaki (Himantopus novaezelandiae)-lessons from 20 years of management. Biol Conservat 105:369-374

Kitchener AC, Birks JDS (2008) Ferret. In: Harris S, Yalden DW (eds) Mammals of the British Isles: handbook, 4th edn. The mammal society, Southampton, UK, pp 485-487

Konecny MJ (1987) Food habits and energetics of feral house cats in the Galapagos Islands. Oikos 50:24-32

Korpimäki E, Norrdahl K (1989) Avian predation on mustelids in Europe. 1. Occurrence and effects on body size variation and life traits. Oikos 55:205-215

Kowalski SP, Domek JM, Deahl KL, Sanford LL (1999) Performance of Colorado potato beetle larvae, Leptinotarsa decemlineata (Say), reared on synthetic diets supplemented with sodium glycoalkaloids. Am J Potato Res 76:305-312

Krebs CJ (1999) Ecological methodology, 2nd edn. Addison Wesley Longman Inc

Levins R (1968) Evolution in changing environments. Princeton University, Princeton
Litvaitis JA, Mautz WW (1976) Energy utilization of 3 diets fed to a captive red fox. J Wildl Manag 40:365-368

Litvaitis JA, Mautz WW (1980) Food and energy use by captive coyotes. J Wildl Manag 44:56-61

Lode T (1997) Trophic status and feeding habits of the European polecat Mustela putorius L. 1758. Mamm Rev 27:177-184

Lode T (2003) Sexual dimorphism and trophic constraints: prey selection in the European polecat (Mustela putorius). Ecoscience 10:17-23

Luxmore R (2008) Canna seabird recovery project. Final report to EU LIFE - National Trust for Scotland, Edinburgh, UK

Lyver PO'B (2000) Identifying mammalian predators from bite marks: a tool for focusing wildlife protection. Mamm Rev 30:31-43

McDonald RA (2002) Resource partitioning among British and Irish mustelids. J Anim Ecol 71:185-200

Macdonald DW, Harrington LA (2003) The American mink: the triumph and tragedy of adaptation out of context. New Zeal J Zool 30:421-441

McDonald RA, Webbon C, Harris S (2000) The diet of stoats (Mustela erminea) and weasels (Mustela nivalis) in Great Britain. J Zool 252:363-371

Mills RG (1994) Rabbit predators in the semi-arid high country of the South Island of New Zealand. MSc thesis, Lincoln University, New Zealand.

Mitchell PI, Newton SF, Ratcliffe N, Dunn TE (2004) Seabird populations of Britain and Ireland: results of the 'Seabird 2000' census 1999-2002. Poyser, London

Moors PJ (1977) Studies of metabolism, food-consumption and assimilation efficiency of a small carnivore, weasel (Mustela nivalis L). Oecologia 27:185-202

Moors PJ (1980) Sexual dimorphism in the body size of mustelids (Carnivora) - the roles of food-habits and breeding systems. Oikos 34:147-158

Murphy EC, Keedwell RJ, Brown KP, Westbrooke I (2004) Diet of mammalian predators in braided river beds in the central South Island, New Zealand. Wildl Res 31:631-638

Nagy KA (2005) Field metabolic rate and body size. J Exp Biol 208:1621-1625

Newton I, Davis PE, Davis JE (1982) Ravens and buzzards in relation to sheep-farming and forestry in Wales. J Appl Ecol 19:681-706

Norbury G (2001) Conserving dryland lizards by reducing predatormediated apparent competition and direct competition with introduced rabbits. J Appl Ecol 38:1350-1361

Norbury G, Heyward R (2008) Predictors of clutch predation of a globally significant avifauna in New Zealand's braided river ecosystems. Anim Conservat 11:17-25

Norbury GL, Norbury DC, Heyward RP (1998) Behavioral responses of two predator species to sudden declines in primary prey. J Wildl Manag 62:45-58

Pianka ER (1973) The structure of lizard communities. Annu Rev Ecol Systemat 4:53-74

Pitta Groz M, Pereira JC, Silva AG (2002) Invasive alien species as the main threat to Azores seabird populations. In: Proceedings of a workshop on invasive alien species on European islands and evolutionary isolated ecosystems, Horta, Azores, Portugal pp. 7-8

Poole TB (1972) Some behavioral differences between European polecat, Mustela putorius, ferret, $M$ furo, and their hybrids. J Zool 166:25-35

Powell RA, Leonard RD (1983) Sexual dimorphism and energyexpenditure for reproduction in female fisher Martes pennanti. Oikos 40:166-174

Powell RA, Clark TW, Richardson L, Forrest SC (1985) Black-footed ferret Mustela nigripes energy-expenditure and prey requirements. Biol Conservat 34:1-15

Powers JG, Mautz WW, Pekins PJ (1989) Nutrient and energy assimilation of prey by bobcats. J Wildl Manag 53:1004-1008 
Quinn JH, Whisson DA (2005) The effects of anthropogenic food on the spatial behaviour of small Indian mongooses (Herpestes javanicus) in a subtropical rainforest. J Zool 267:339-350

Quy RJ, Macdonald DW (2008) Brown rat. In: Harris S, Yalden DW (eds) Mammals of the British Isles: handbook, 4th edn. The mammal society, Southampton, UK, pp 149-155

Ragg JR (1998) Intraspecific and seasonal differences in the diet of feral ferrets (Mustela furo) in a pastoral habitat, east Otago, New Zealand. New Zeal J Ecol 22:113-119

Ragg JR, Mackintosh CG, Moller H (2000) The scavenging behaviour of ferrets (Mustela furo), feral cats (Felis domesticus), possums (Trichosurus vulpecula), hedgehogs (Erinaceus europaeus) and harrier hawks (Circus approximans) on pastoral farmland in New Zealand: implications for bovine tuberculosis transmission. New Zeal Vet J 48:166-175

Rebergen A, Keedwell R, Moller H, Maloney R (1998) Breeding success and predation at nests of banded dotterel (Charadrius bicinctus) on braided riverbeds in the Central South Island, New Zealand. New Zeal J Ecol 22:33-41

Reynolds JC, Aebischer NJ (1991) Comparison and quantification of carnivore diet by fecal analysis - a critique, with recommendations, based on a study of the fox Vulpes vulpes. Mamm Rev 21:97-122

Roemer GW, Donlan CJ, Courchamp F (2002) Golden eagles, feral pigs, and insular carnivores: how exotic species turn native predators into prey. Proc Nat Acad Sci Unit States Am 99:791-796

Roy SS (2006) Mink control to protect important birds in the SPAs in the Western Isles. Final report to EU LIFE III-Nature, Scottish Natural Heritage, Edinburgh

Short HL (1961) Food habits of a captive least weasel. J Mammal $42: 273-274$

Sibbald IR, Evans EV, Smith DLT, Sinclair DG (1962) Rate of passage of feed through digestive tract of mink. Can J Biochem Physiol 40:1391-1394

Sinclair ARE, Pech RP, Dickman CR, Hik D, Mahon P, Newsome AE (1998) Predicting effects of predation on conservation of endangered prey. Conservat Biol 12:564-575
Smith GP, Ragg JR, Moller H, Waldrup KA (1995) Diet of feral ferrets (Mustela furo) from pastoral habitats in Otago and Southland, New Zealand. New Zeal J Zool 22:363-369

Snow D, Perrins CM (1994) The birds of the Western Palearctic, concise edition. Oxford University, Oxford

Sotherland PR, Rahn H (1987) On the composition of bird eggs. Condor 89:48-65

Soulé ME, Bolger DT, Alberts AC, Wright J, Sorice M, Hill S (1988) Reconstructed dynamics of rapid extinctions of chaparral-requiring birds in urban habitat islands. Conserv Biol 2:75-92

Strayer DL, Eviner VT, Jeschke JM, Pace ML (2006) Understanding the long-term effects of species invasions. Trends Ecol Evol 21:645-651

Taylor RH (1979) How the Macquarie Island parakeet became extinct. New Zeal J Ecol 2:42-45

Teerink BJ (1991) Hair of West European mammals. Cambridge University, Cambridge

Trout RC, Ross J, Tittensor AM, Fox AP (1992) The effect on a British wild rabbit population (Oryctolagus cuniculus) of manipulating myxomatosis. J Appl Ecol 29:679-686

van Dijk J, Hauge K, Landa A, Andersen R, May R (2007) Evaluating scat analysis methods to assess wolverine Gulo gulo diet. Wildl Biol 13:62-67

Veitch CR, Clout MN (eds) (2002) Turning the tide: the eradication of invasive species (Proceedings of the international conference on eradication of island invasives). IUCN, Gland, Switzerland and Cambridge, UK

Votier SC, Bearhop S, Ratcliffe N, Phillips RA, Furness RW (2004) Predation by great skuas at a large Shetland seabird colony. J Appl Ecol 41:1117-1128

Williams JB, Anderson MD, Richardson PRK (1997) Seasonal differences in field metabolism, water requirements, and foraging behaviour of free-living aardwolves. Ecol 78:2588-2602

Wolfe A, Long AM (1997) Distinguishing between the hair fibres of the rabbit and the mountain hare in seats of the red fox. J Zool 242:370-375 